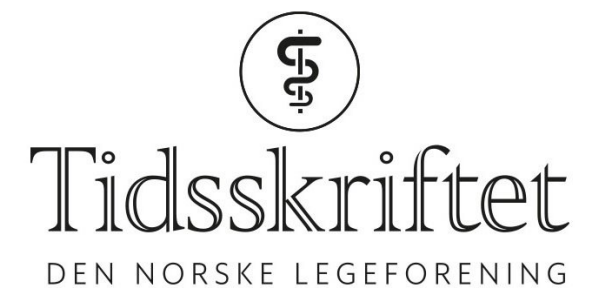

DEN NORSKE LEGEFORENING

\title{
Veilederordningen - nært eller fjernt fra mentorordninger?
}

LEGELIVET

CECILIE NORMANN BIRKELI

E-post: cecilie.normann@legeforeningen.no LEFO - Legeforskningsinstituttet

At veiledning i spesialistutdanningen har stor betydning i utdanningsløpet er godt dokumentert nasjonalt og internasjonalt. Men hvorfor er veiledning viktig i utdanningen og hvordan kan den bli en ressurs for leger i spesialisering?

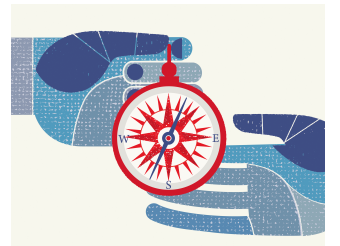

I en nylig publisert oversiktsartikkel drøfter forfatterne nettopp dette (1). I den internasjonale forskningslitteraturen brukes begrepene «mentoring» og «mentorordninger». Dette tilsvarer omtrent det norske begrepet veiledning, men en mentorordning innebærer både en veilederrolle og ansvar for kandidatenes utdanning (1). Studien omhandler helseprofesjoner som har innført mentorordning som en del av formalkompetansen i utdanningen, og gir en oversikt over ulike modeller av mentorordninger som eksisterer, og hva disse innebærer og medfører av ansvar.

Å bli veiledet antas å ha stor innflytelse for den personlige utviklingen, karriereveiledning og karrierevalg. Nyere forskning viser at mentorer bidrar signifikant til utviklingen av kandidatenes ferdigheter innen forskning, undervisning, klinisk arbeid og nettverksbygging (1). Gjennom veiledning kan læringskurven hos nye kandidater forbedres gjennom både formell og uformell deling av kunnskap og erfaringer. Å utdanne seg på arbeidsplassen innebærer utvikling av kunnskap og ferdigheter. I dette ligger det også en forståelse av verdier som er viktig for profesjonen og organisasjonskultur.

Men veiledning er ikke bare nyttig for dem som blir veiledet (1). De som veileder får muligheter til å dele av sine erfaringer og kunnskap, og de blir mer oppmerksom på egne profesjonelle evner og måter å utøve praksis på. De får også innsikt i andre deler av organisasjonen og det settet av verdier og kulturer som finnes der, noe som kan være nyttig.

Når mentorforhold varer over tid, kan det også oppstå potensielle vansker med interessekonflikter mellom kandidat og mentor. De kan for eksempel handle om ubalansen i maktforholdet eller urealistiske forventninger til hva en mentor skal være. Det er viktig å kunne forutse dette, men også å håndtere slike situasjoner hvis de oppstår. 
Selv om mentor- og veilederordninger er forskjellige i ulike helsesystemer i ulike land, viser altså forskningen at veiledning har positiv effekt i utdanningen, både for den som blir veiledet og den som veileder, sammenlignet med land eller systemer som ikke har dette som et formalisert opplegg.

En av de største utfordringene i Norge har tidligere vært at det i en hektisk arbeidshverdag ikke er blitt avsatt nok tid til veiledning (2). Dermed har spesialistkandidatene ofte gått glipp av det læringspotensialet som ligger i veiledning og den støttemekanismen veiledning er ment til å være underveis i spesialistløpet. I den nye modellen for spesialistutdanningen er det bestemt at veiledningen skal styrkes, og det skal settes av tid til den underveis. Det er viktig at et strukturert veiledningsopplegg for leger i spesialisering gjennom hele utdanningsløpet tilstrebes og formaliseres i større grad.

\section{LITTERATUR:}

1. Burgess A, van Diggele C, Mellis C. Mentorship in the health professions: a review. Clin Teach 2018; 15: 197 - 202. [PubMed][CrossRef]

2. Birkeli CN. Nasjonal evaluering for spesialistutdanningen for leger 2016. Oslo:

Legeforskningsinstituttet, 2017.

http://legeforeningen.no/PageFiles/283794/Nasjonal\%2oevaluering\%20av\%2ospesialistutdanningen\%20 for\%2oleger\%2oLEFO\%202017.pdf(27.6.2018).

Publisert: 21. august 2018. Tidsskr Nor Legeforen. DOI: 10.4045/tidsskr.18.0516

(C) Tidsskrift for Den norske legeforening 2020. Lastet ned fra tidsskriftet.no 